\title{
Sustainability Concept in Ecotourism on Domestic Tourists of Generation Z
}

\author{
Joyo Binangun ${ }^{1}$, I Dewa Gde Satrya ${ }^{2 *}$ \\ ${ }^{I}$ Student of Hotel \& Tourism Business, School of Tourism, Universitas Ciputra Surabaya, Indonesia \\ ${ }^{2}$ Lecture of Hotel \& Tourism Business, School of Tourism, Universitas Ciputra Surabaya, Indonesia \\ *Corresponding author.Email: dewa.gde@ciputra.ac.id
}

\begin{abstract}
The purpose of this research is to find out the concept of sustainability in ecotourism in generation $Z$ domestic tourists. The location of this research was conducted in Baluran National Park. This study uses a qualitative approach in which the data collected in the form of interviews, observation and documentation. The data analysed were the results of interviews with one expert from ecotourism, one manager from Baluran National Park, four Generation $Z$ visitors and observations in the Baluran National Park environment. Data analysis techniques use data collection, data reduction, and coding in accordance with the themes discussed. Data collection methods use data triangulation techniques that are useful for establishing degrees of trust. The results of this study are the concept of understanding the importance of sustainability in ecotourism in generation $Z$ domestic tourists is still lacking. There is awareness from generation $Z$ about the importance of sustainable tourism, but there is still a lack of interest in participating in nature-based organizations because it does not attract packaging from the institution itself. In addition, there is still a lack of literacy reading among generation $Z$ regarding natural knowledge, so Baluran National Park can create an interesting program for generation $Z$ regarding basic understanding of nature in the form of online media.
\end{abstract}

Keywords: sustainability, ecotourism, generation Z

\section{INTRODUCTION}

In Academia.edu [1], to maintain sustainability of the local people's income from natural tourism, local people must pay attention to preservation and protect the tourism environment. Nonetheless the fact is that there are still many Indonesian people who still do not care and understand the need for environmental preservation related to conservation that is not in accordance with the environment, tourists will understand the role of forests and liars in life defenders, who spend the potential of the natural tourism environment.

One of the well-known tourist attractions in Indonesia is Baluran National Park in Situbondo, East Java. This national park is known by the name African Van Java because it has a vast savanna field similar to Africa. This area was created as a conservation place because of the protected flora and fauna according to Indonesiabaik.id. Consistent with Santoso [2] declares the generation $\mathrm{Z}$ or Millennials generation was born in 1994. This generation has a high education level, diversity, and use of technology. Generation Z has an awareness of a green lifestyle and an obligation to its environment. They have an interest in buying green products even though they are still young, as said by Noor, Jumain, Yusof, Ahmat, and Kamaruzaman [3]. Andrea, Gabriella, and Tímea [4] utter in the study outcome with employee respondentsunder the age of 30, explained that generation $\mathrm{Z}$ has the characteristics of a level of confidence that is too high, creative, has a strong career desire, committed, and hardworking. Goh and Lee [5] states that generation X with births in 1979 have the same characteristics as generation $\mathrm{Y}$ with births in 1980. In previous studies reported that there were significant differences in characteristics 


\section{Procedia Business and Financial Technology}

Proceedings of the 2nd International Conference on Business and M anagement of T echnology (ICO N BM T 2020) - Part 2

of generation Z. Therefore, they determined that generation $\mathrm{Z}$ had born in 1995 to 2009 .

Darmawan \& Fadjarajani [6], defines a tourism environment that has naturalbeauty, unique culture and souvenirs will cause tourists to love nature. The preservation of the environment can be done by using materials that can be recycled as a goal to minimize the use of plastic waste and can also make the area a conservation area to protect the wildlife ecosystem.All these improvements should be done by coordination, synergy, and consistency among stakeholders of tourism [7].

Postma, Cavagnaro and Spruyt [8] stated that the development of this era should be able to pay attention to the dangers of adverse effects that will be received by the environment. Change should be made not only from ecology and economics, but also from individuals, groups and human organizations as well. Formulation of the problem in this study is how the sustainability concepts in ecotourism in Generation $\mathrm{Z}$ domestic tourists?

\subsection{Theory Study}

\subsubsection{Sustainability}

Postma, Cavagnaro, and Spruyt testifies current developments are financially, socially and environmentally unbalanced, followed by developments in the modern world and especially in the tourism industry cannot find their needs without jeopardizing their future. Evita, Sirtha and Sunartha [9] in the development of sustainable tourism, they should avoid mass tourism. Economically, the increasing number of tourists has a positive impact on a country's economy. But the opposite has a negative effect on the environment. One effort to reduce the negative impact of mass tourism, is the development of alternatives that are more concerned with environmental sustainability and also the development of sustainable tourism.

UNEP and UNWTO in the book Making Tourism more Sustainable, P.26-47, about Sustainability of Tourism Agenda which explains about sustainable indicators as follows[10]:

1) Economic Viability, to make sure survival and competition in tourist destinations and companies so that they can prosper and benefit in the long run. Thepolicy can be organized by:
a) Understand the Market.
b) Provide visitor satisfaction.
c) Maintaining good trading conditions.
d) Maintain and project attractive tourist destinations.
e) Provide business support.

2) Local Prosperity, to make sure tourism contribution in economic prosperity to local residents, including in the visitors' expenditure section. The policy can be organized by:

a) Lessening profit leakage taken by external investors.

b) Strengthening relationships among businesses.

c) Affects the visitor spending level.

3) Employment Quality, to strengthen the quality and quantity of local jobs created andsupported by tourist attractions, including salary, service conditions, availability of employment without discrimination of sex, race, and disability in any way. The policy can be organized by:

a) Increase job opportunities and parts throughout the year, full time employment.

b) Confirm and enforce labor regulations.

c) Encouraging companies to provide workforce training programs.

d) Pay attention to the welfare of workers who have lost their jobs.

4) Social Equity, to seek widespread profits and equitable distribution under social economy through the community, including in increasing opportunities, income and services to the poor. The policy can be organized by:

a) Develop income opportunities for people who have less income.

b) Make use of income from tourist attractions to support social programs.

5) Visitor Fulfillment, to provide security, satisfaction, and meeting the visitor experience, without discrimination of gender, race, and disability in any way. The policy can be organized by:

a) Improve access for all visitors.

b) Providing vacation packages to people who have economic or social shortcomings.

c) Pay attention to the safety of visitors.

d) Monitor and handle visitor satisfaction and the quality of visitor experience.

6) Local Control, involving and strengthening local communities in planning and decision making regarding the management and development of tourism in the upcoming. The policy can be implementedby:

a) Ensuring the suitability of the agreement and the empowerment of the local community.

b) Improve local conditions in effective decision making.

c) Address the originality and traditions of the community by respecting localsupervision.

7) Community Wellbeing, to maintain and strengthen the quality of life of local communities, including in socio-cultural and access to resources, facilities and life support systems, avoiding environmental or social exploitation in any form. The policy can be implemented by: 


\section{Procedia Business and Financial Technology}

Proceedings of the 2nd International Conference on Business and M anagement of T echnology (ICO N BM T 2020) - Part 2

a) Get a balance in the volume, time and location of the visit.

b) Reducing the density of visitors.

c) Be careful in the planning andmanagement of corporate tourism andinfrastructure.

d) Promote the use of facilities and services well from residents and tourists.

e) Influence tourist behavioron local communities.

8) Cultural Richness, respecting and enhancing historical heritage, cultural originality, tradition and distinctiveness in local communities. The policy can be implemented by:

a) Ensuring the effectiveness of management and conservation of culture and heritage.

b) Work with sensitive communities and promote culture and tradition.

9) Physical Integrity, maintain and improve the views quality of urban and rural areas andavoid physical and visual degradation of the environment. The policy can be implemented by:

a) Ensuring that the development of new tourism is appropriate for local environmental conditions.

b) Minimize the physical impact of tourist activities.

c) Maintaining the quality of urban and rural resources.

10) Biological Diversity, supports conservation of natural areas, habitats and wildlife, and minimizes damage. The policy can be implemented by:

a) Collaborate with national parks and other conservation areas.

b) Promote the development and management of ecotourism.

c) Use tourism to support landowners to learn about sustainable land management.

d) Cooperating with privateparks.

e) Minimizing damage to the natural heritage of tourism.

f) Increase visitor awareness ofbiodiversity.

g) Increase support for conservation from visitors and companies.

11) Resource efficiency, minimizing the use of scarce and non-renewable resources in the development and operation of tourism in facilities and services:

a) Consider the resources supply intourism development planning and vice versa.

b) Minimizing the use ofwater fromthe tourism sector.

c) Ensuring the effectiveness of the use ofland and raw materials in tourism development.

d) Promote mental of 3R (Reduce, Reuse, and Recycle).

12) Environmental Purity, minimizing air, water and soil pollution and waste generation by companies and visitors. The policy can be implemented by:

a) Promote deeper use of sustainable transportation.

b) Reducing the use of chemicals to damage the environment.

c) Avoid disposal of sewage in the marine and river environments.

d) Minimizing waste.

e) Influence facilities in thedevelopment ofnew tourism.

Asmelash and Kumar [11] discovered thereare several indicators of Sustainability, namely:

1. Economic Sustainability
a. Employment Quality
b. Economic Viability
c. Local Prosperity

2. Environment Sustainability

a. Physical Integrity

b. Biological Diversity

c. Resource Efficiency

d. Environmental Purity

3. Socio - Cultural Sustainability

a. Social Equity

b. Visitor Fulfillment

c. Local Control

d. CommunityWellbeing

e. Cultural Richness

4. Institutional Sustainability

a. Local-Oriented Control Policy

b. Political Participation

c. Local Planning Policy

d. Political Support at Different Levels of

Government

\subsubsection{Ecotourism}

As said by Pamungkas [12] ecotourism is an environmentally friendly activity that adopts the sustainable tourism principle. Lovelock [13] describe organizational relations, working together is an important thing for the participation of stakeholders involved in ecotourism management to develop the concept of sustainable tourism.

While Fennel [14] explains ecotourism is a form of tourism with a sustainable natural resource base that focuses primarily on experience and learning about nature. Ecotourism can be managed to minimize impacts, not be consumptive, and locally oriented. Ecotourism is in a natural environment and must contribute to environmental conservation and preservation.

Honey [15] describing ecotourism as a trip to the original place which is usually a protected area that is sought to have a low impact and is usually small scale. This helps in educating tourists, providing funds for conservation, having a direct impact on the local economy, fostering appreciation for cultural differences and human rights. Razak [16] explains that there are several policies in the 


\section{Procedia Business and Financial Technology}

Proceedings of the 2nd International Conference on Business and M anagement of T echnology (ICO N BM T 2020) - Part 2

development of ecotourism, namely:

1. The natural and socio-cultural environment must be the basis of development without endangering its sustainability.

2. Ecotourism is very dependent on the quality of the natural environment and good social culture.

3. The organizations existence that manage conservation areas must be maintained sustainably, good management of and for tourists, mutual information in management with tourism operators, local communities and provide appropriate economic potential.

4. Tourists can enjoy various facilities and activities that can provide new knowledge in traveling, it's just that not all the needs of tourists can be met or not in accordance with the relevant conservation goals.

5. Tourists tend to expect good quality of service that matches the costs incurred and they are not always interested in cheap services.

6. Desires vary from tourists depending on the nature of the characteristics.

7. Planning must be faster and carried out in a sustainable manner as ecotourism develops, including in inventorying existing components in the national park area, especially matters affecting tourists

Randall [17] explains that international ecotourism institutions have principles that must be obeyed in participating in ecotourism, namely:

1. Minimize impact.

2. Building cultural and environmental awareness.

3. Providing positive experience for visitors and owners.

4. Providing direct financial benefits for conservation land.

5. Providing financial benefits and empowerlocal communities.

6. Increase awareness of the country politically, environmentally and sociallyclimate.

7. Support human rights and labor.

Attitudes towards sustainability in ecotourism are developed by indicators and measurements by Nowaszec and Smale [18]. The indicators are:
1. Ethics,
2. Culture,
3. Nature,
4. Education,
5. Contributions,
6. Specialization.

\subsubsection{Generation $Z$}

Santoso [2] stated that generation $\mathrm{Z}$ or the millennials was born in 1994. This generation has a high level of education, diversity, and use of technology. According to Haddouche and Salomone [19] Generation Z was born and grew up aroundtechnology and the internet, equipped with smartphones, games. Sending messages through smartphones, liking photos from Instagram, is part of the generation $\mathrm{Z}$ that is inseparable from daily life. The life of generation $\mathrm{Z}$ is everywhere, because of the global playground. They play with friends who could be in a place far from him. According to Goh and Lee [5] states that generation $\mathrm{X}$ with births in 1979 have the same characteristics as generation Y with births in 1980s. In previous studies reported that there were significant differences in characteristics of generation $\mathrm{Z}$. Therefore, they determined that generation $Z$ who born in 1995 to 2009. Generation $Z$ has an awareness of a green lifestyle and an obligation to its environment. They have an interest in buying green products even though they are still young, according to Noor, Jumain, Yusof, Ahmat, and Kamaruzaman [3].

\subsection{Research Methods}

Grounded on the topics studied, the researcher will use Qualitative research methods. Qualitative research is a scientific research that points to understand a social context phenomenon in a scientific manner by prioritizing deep communication interaction process between researchers and the phenomena studied by Herdiansyah [20].

In this study, the researcher becomes an observer who will observe the behavior of generation $\mathrm{Z}$ domestic tourists in Baluran National Park.

Informants in this study are:

1. M. Nurdin Razak (owner of baloeranecolodge.com in Baluran National Park and as an ecotourism specialist)

2. Arif Pratiwi

This informant was chosen because she has a position as the coordinator of the visitor program planning and the tourism, he is familiar with the field conditions and knows the development of Baluran National Park in general.

3. Generation $\mathrm{Z}$ domestic tourists

These informants were selected as many as four people who had visited Baluran National Park at least once, aged 11 to 26 years, had a background in participating in the ecotourism conservation community, and visited Baluran National Park without bringing garbage.

Primary data sources from observation in Baluran National Park and interview the informant, secondary data from the literature. In data collection, the researcher uses several methods so will use data triangulation techniques. According to Gunawan [19] data triangulation is used to establish the degree of trust and consistency of the data, as well as being useful in the process of data analysis in 


\section{Procedia Business and Financial Technology}

Proceedings of the 2nd International Conference on Business and M anagement of T echnology (ICO N BM T 2020) - Part 2

thefield.

\subsection{Discussion}

Based on the results of data analysis that has been collected from sources, the discussion of each indicator is based on the results of triangulation of data as follows:

\subsubsection{Ethics}

Razak [16] explains that there are several policies in developing ecotourism, one of which is the natural and socio-cultural environment must be the basis of development without endangering its sustainability. So the natural environment must be treated with respect by all generations, not only generation $\mathrm{Z}$. According to Ms. Arif Pratiwi as the coordinator at Baluran National Park, the natural environment must be treated with respect.

"Clearly by all generations, not only generation Z."

Not only Ms. Arif Pratiwi, according to Mr. Nurdin as Specialist Ecotourism also said so.

"Yes, we have to ... because humans cannot live without nature, even though generation $Z$ is not compulsory."

Apart from that humans must protect the natural environment even though it cannot be visited, the entire generation of $Z$ supports this.

One generation $\mathrm{Z}$ said, "Yes, it must be protected even though there are no visitors, it must be protected so that it does not become damaged, it is sustainable. This statement was also supported by Mr. Nurdin, he said that,

"Because whoever man comes back again, every individual on earth needs water and water is in nature... visited or not needs water stored in nature, that's a concrete example, yes."

Besides Mr. Nurdin, Arif Pratiwi also said that

"... in Baluran there is a core zone, it can be visited but only for research purposes but not for tourism ... so generation $Z$ should also be respectful of the decision because there are all studies why there is a core zone because tourism is not permitted to the zone"

In accordance with being in a theoretical study according to UNEP and UNWTO on one of the indicators of sustainable tourism indicators, namely physical integrity which contains maintaining the quality of views from urban or rural areas and avoiding physical and visual deterioration of the environment. This point has several policies, one of which is to minimize the impact of tourist activities. The core zone in Baluran National Park does not allow ordinary visitors to enter inside. This zone only allows visitors who have the goal of doing research.

Based on interviews with informants, generation $\mathrm{Z}$ said that they value cultural diversity.
"Yes, respect ... Yes, it must be respected, because we also live not only humans but also many other creatures like trees are also living things, right? Animals thenwe must respect each other. "

"Yes, respect, because of a gold country because the work of each region is gold."

"Alhamdulillah, I appreciate it ... I still respect it, the problem is still what I like the diversity of Indonesian culture."

"Oh, we have to mean what we mean, especially on our own, for example, if we are tribally different, we mean that when we travel, we must be different, the diversity is different and certainly very striking, maybe there are a number of the same, but there are different, and we also have to respect that means we go into someone else's room

However, according to Arif Pratiwi, there are still many generations $\mathrm{Z}$ who still do not appreciate cultural diversity.

"May I say not all of them, but there are indeed a few, maybe some do not appreciate it, a variety of causes and backgrounds, why is that?"

This statement is supported by Mr. Nurdin,

"I see it's still lacking ... generation zis weak in literacy, second Generation $Z$ is weak in understanding local culture which means it is art culture and all kinds ..."

So, generation $\mathrm{Z}$ is still weak in appreciating the diversity of cultures that Indonesia has. Even though Indonesia has cultural diversity in eachregion.

\subsubsection{Culture}

Randall [17] suggests that there are several principles in international institutions that must be obeyed in participating in ecotourism, one of which is to build cultural and environmental awareness. Each region has its own local culture, but not all generation $\mathrm{Z}$ can accept the local culture. According to one generation $\mathrm{Z}$ said that he can accept the localculture,

"Yes, yes, we have to accept it. When in the other place, we have to, however if the culture is good, we still have to accept it if it's bad, it's not just being insulted, just being avoided."

Arif Pratiwi said that there are local cultural activities carried out by Banyuputih people, one of which is Sea Picking. This sea picking is an activity with the aim to symbolize thanksgiving to God for giving abundant fish. This tradition is held every year from February to March depending on Javanese calculations. Generation $\mathrm{Z}$ also enlivens this tradition so that they will continue to respect their culture. 


\section{Procedia Business and Financial Technology}

Proceedings of the 2nd International Conference on Business and M anagement of T echnology (ICO N BM T 2020) - Part 2

However, according to Mr. Nurdin Razak, instead the generation $\mathrm{Z}$ is declining in accepting local culture, generation $\mathrm{Z}$ only knows the local culture only from digital media.

"I see less and more ... just know enough from digital media but they don't visit at that segment level except in entertainment."

\subsubsection{Nature}

The natural environment is vital in traveling, because some people use nature to eliminate the boredom of routine in the city. According to Noor et all (2017) Generation $\mathrm{Z}$ has an awareness of eco-friendly lifestyles and has an obligation to the environment. Generation $\mathrm{Z}$ has an interest in eco-friendly products even though it is still quite young. According to one generation $\mathrm{Z}$ said that, "... we want to get out of the routine zone of the urban to the place where has a natural nuance, so it is an option that can be relaxing, right?

And the statement is the same as what was said by Mr. Nurdin who considered that Generation $\mathrm{Z}$ traveling to the natural environment aims to eliminate routine boredom in the city.

"I see it is crucial... because they are tired of the situation in the city."

\subsubsection{Contributions}

Mr. Nurdin said, it is important to support conservation groups and organizations in nature. According to Lovelock [13] organization is an important thing to participate in the community which involves the management of ecotourism to focus on developing the concept of sustainable tourism. This was also supported by Arif Pratiwi, who started itearly.

"Yes, we want to start from elementary school because that's what will be carried out until he grows up and it has to start from there ... let alone like conservation groups, we form and train conservation cadres and scouts like them so they can care more about natural"

In addition, according to UNEP and UNWTO about sustainable tourism there are indicator points, namely community wellbeing which contains maintenance and strengthening the quality of life in local communities, including on socio-culture and access to resources, facilities and life support systems. This serves to avoid any kind of environmental or social exploitation.

Baluran national park managers to learn about nature in the surrounding community since childhood.

However, not all generations $Z$ are interested in participating in nature rehabilitation. One generation $Z$ said that he was not interested in participating.

"Not the members."
Mr. Nurdin believes that generation Z's participation in natural rehabilitation depends on how the program is introduced.

"... that interest has to do with how the program was introduced ... if the conventional program wrapped in attractive packing, of course they will refuse. "

If the program is introduced with attractive packaging, generation $\mathrm{Z}$ may be interested in participating in nature rehabilitation.

Generation $\mathrm{Z}$ is also interested in making a donation in the conservation group, because the action is a positive thing according to one generation $\mathrm{Z}$.

"If there is, donate for positive things too."

\subsubsection{Education}

Honey [15] explains that ecotourism is a trip to a protected area and has a low impact and small scale. This serves to educate tourists to have a direct impact on the local economy, foster appreciation for cultural differences and human rights.

In learning new cultures, most generations of $\mathrm{Z}$ have an interest. But there are some who are not interested in learning it, just enjoy it. According to Arif Pratiwi, there are indeed some generation $\mathrm{Z}$ who are interested in learning new cultures.

"Some, some are indeed because it is something new because they are happy to explore ... but there are those who are not interested, it depends on the hobbies of each generation, there are those who are truly happy, some are not there."

\subsubsection{Specialization}

According to one generation $\mathrm{Z}$ the importance of participating in a community or organization based on nature is useful to provide knowledge about nature.

"It is important, we from the community know how to care for nature, so that it is not damaged, the problem is that like in the beginning, it was natural that if wewere to keep it good, it would be beneficial tous."

In addition, the addition of Arif Pratiwi, namely the importance of participating in community or nature- based organizations will foster the character and mentality of the Generation $\mathrm{Z}$ to theirenvironment.

"It is important for their personal development, physically and mentally ... because nature is notmerely a matter of brave heat, but group interaction facing challenges in nature will also be good for his mental development."

Haddouche and Salomone [19] supposed that Generation $\mathrm{Z}$ was born and grew up around technology equipped with Smartphones, Games. This is part of generation $\mathrm{Z}$ which cannot be separated from everyday life. So it is clear that 


\section{Procedia Business and Financial Technology}

Proceedings of the 2nd International Conference on Business and M anagement of T echnology (ICO N BM T 2020) - Part 2

not all $\mathrm{Z}$ generations are interested in reading magazines about nature, they prefer to read through articles that are on the internet. This was also supported by Arif Pratiwi and Nurdin on the interest of generation $\mathrm{Z}$ in reading magazines that are still low, but generation $\mathrm{Z}$ will be more interested in visual learning media.

"... but if you combine it with photos, you will be more attracted."

"... generation Z literacy ability was weak because it was accustomed to visual ... literacy in the form of visual, visual literacy is also in the form of images. "

Because some Generation $\mathrm{Z}$ said that they were not interested in reading literacy in the form of magazines. Theyare more interested in reading in the media on the Internet.

"In magazine form that is not interested."

"Honestly, magazines, I don't mean that they don't subscribe to it, but now there are a lot of media that we can use to, which means reading or searching ... that means people who are travelers"and now there are lots of stories about explorations in many places."

\section{CONCLUSION}

Founded on the study results conducted by researchers concluded that the sustainability concept in ecotourism is that the natural environment has a great role on humans, they provide resources to the living creatures in the vicinity, then there must be a preservation of ecotourism in order to remain sustainable for generations to come. The role of generation $\mathrm{Z}$ in sustainability today is very important, because if generation $\mathrm{Z}$ has no awareness and movement in keeping ecotourism sustainable then the thing that will happen is the extinction of living things in the natural environment in the future. As a result, humans will lose all natural resources. This can be overcome by providing education to Generation $\mathrm{Z}$ regarding biodiversity and support from Baluran National Park Managers to grow awareness and movement from Generation $\mathrm{Z}$ on the importance of preserving the natural environment as stated in UNEP and UNWTO on sustainable tourism in one of the biological indicator points diversity.

\section{ACKNOWLEDGMENT}

This research is the final assignment of the first writer in the tourism study program (hotel and tourism business), Universitas Ciputra University Surabaya (2020).

\section{REFERENCES}

[1] Academiaedu, "Makalah Pelestarian Lingkungan Hidup"." [Online]. Available: https://www.academia.edu/7263193/Makalah_

[2] G. Santoso, "Gaya Pengambilan Keputusan Generasi Z di Indonesia dalam Pembelian Pakaian Secara Online. Parsimonia," vol. 4, no. 3. pp. 291300, 2018.

[3] M. Noor, R. Jumain, A. Yusof, M. Ahmat, and I. Kamaruzaman, "Determinants of Generation $Z$ green purchase decision: A SEM-PLS approach," International Journal of Advanced and Applied Sciences, p. 146, 2017.

[4] B. Andrea, H. Gabriella, and J. Timea, "Y and Z Generations at Workplaces," Journal of Competitiveness, vol. 8, no. ue 03, pp. 90-106, 2016.

[5] E. Goh and C. Lee, "A Workforce to be reckoned with: The Emerging pivotal Generation Z hospitality workforce," International Journal of Hospitality Management, p. 21, 2018.

[6] D. Darmawan and S. Fadjarajani, "Hubungan Antara Pengetahuan dan Sikap Pelestarian Lingkungan dengan Perilaku Wisatawan dalam Menjaga Kebersihan Lingkungan," Geografi, 2016.

[7] M. Y. Anshori, F. K. Denis, D. F, and H. Teguh, "study of Revisit Intention: Beach Image, Beach Uniqueness, Beach Authenticity, Attraction and Satisfaction in Lombok Beach Nusa Tenggara Barat," TEST Engineering \& Management Journal, vol. 83, pp. 2988-2996, 2020.

[8] A. Postma, E. Cavagnaro, and E. Spruyt, "Tourism 2040," Journal of Tourism Futures. EmeraldInsight.com, 2017.

[9] R. Evita, S. I.N, and S. I.N, Dampak Perkembangan Pembangunan Sarana Akomodasi Wisata Terhadap Pariwisata Berkelanjutan di Bali. Jurnal Ilmiah Pariwisata, 2012.

[10] U.N.E.P. and U.N.W.T.O., "Making Tourism More Sustainable - A Guide for Policy Makers.” p. 26-47, 2005.

[11] A. A.G and K. S, Assessing Progress of Tourism Sustainability: Developing and Validating Sustainability Indicators. Tourism Management. India: Patiala, 2019.

[12] G. Pamungkas, "Ekowisata Belum Milik Bersama: Kapasitas Jejaring Stakeholder dalam Pengelolaan Ekowisata (Studi Kasus: Taman Nasional Gunung Gede Pangrango," Jurnal Perencanaan Wilayah dan Kota, vol. 24, no. 01, pp. 49-64, 2013.

[13] B. Lovelock, "Inter organizational relations in the protected area - Tourism Policy Domain," The Influence of Macroeconomic Policy.Current Issues in Tourism, vol. 4, no. 2/4, pp. 253-274, 2001.

[14] D. Fennel, 1999.

[15] M. Honey, "Ecotourism and Sustainable 


\section{Procedia Business and Financial Technology}

Proceedings of the 2 nd International Conference on Business and M anagement of T echnology (ICON BM T 2020) - Part 2

Development. Who owns Paradise?" Island Press Indonesiabaik.id. "Taman Nasional Baluran," Washington D.C, 1999. [Online]. Available: http://indonesiabaik.id/infografis/taman-

[16] M. N. Razak, Ekowisata: Manajemen Kawasan Konservasi, 2017.

[17] J. Randall, p. 10, 2011.

[18] A. Nowaczek and B. Smale, "Exploring the predisposition of travellers to qualify as ecotourists: the Ecotourist Predisposition Scale," Journal of Tourism, 2008.

[19] I. Gunawan, H. Haddouche, and C. Salomone, "Metode Penelitian Kualitatif: Teori dan Praktik," Journal of Tourism, vol. 4, no. ue: 1, p. 69-79, 2014.

[20] H. Herdiansyah, Metodologi Penelitian Kualitatif untuk Ilmu - Ilmu Sosial. Jakarta: Salemba Humanika, 2010 